\title{
The Use of Schematic-activation Strategy in Teaching Young EFL Learners Reading Comprehension
}

\author{
Rima Rahmaniah, Etika Ariyani, Titin Suryani \\ a bc University of Muhammadiyah Mataram, Indonesia, ${ }^{a}$ rimarahmaniah172@gmail.com
}

\begin{tabular}{|c|c|}
\hline ARTICLE INFO & ABSTRACT \\
\hline $\begin{array}{l}\text { Keywords: } \\
\text { Schematic-activation, reading } \\
\text { comprehension, young learners }\end{array}$ & $\begin{array}{l}\text { Reading is one of the important skills that the students have to } \\
\text { master. However, many students have difficulties in comprehending } \\
\text { the reading text. To solve this condition, the researcher used schema } \\
\text { activation strategy to help students understand reading } \\
\text { comprehension. The purpose of this research was to investigate } \\
\text { whether the use of schema activation stategy is efective or not in } \\
\text { teaching reading comprehension at the second grade students of MTs } \\
\text { Tarbiyatul Mustafid in academic year } 2017 / 2018 \text {. This study was } \\
\text { quasi experimental design using two classes were VIII B class was } \\
\text { taken as experimental class and VIII A was taken as control class. } \\
\text { The population of this research involved } 60 \text { students from the second } \\
\text { grade in MTs Tarbiyatul Mustafid Batu Rimpang. By using purposive } \\
\text { sampling the researcher took the students as a sample. In collecting } \\
\text { the data, this study used pre-test, treatment and post-test as the data } \\
\text { collection procedure then followed by analyzing the data by using t- } \\
\text { test formula. Then the result of statistical analysis of t-test in this } \\
\text { research was } 2.85 \text {. It was higher that critical values for t- table in } \\
\text { degree of freedom (df) of } 58 \text { is } 2.021(0.05 \%) \text { and } 2.704(0.01 \%) \text {. The } \\
\text { researcher concludes that mean score before and after taught by using } \\
\text { schema activation strategy has difference. It means the alternative } \\
\text { hypothesis (ha) was definitely accepted. The use of schema activation } \\
\text { strategy in teaching reading comprehension at the second grade } \\
\text { students of MTs Tarbiyatul Mustafid Batu Rimpang is effective. }\end{array}$ \\
\hline
\end{tabular}

\section{Introduction}

Language is a tool of communication used by people to connect each other. By language they will be easy to express their ideas, opinions, feelings, etc. There are many languages in the world. English is one of the languages used as international language for communication. Many people want to learn English in order to be able to communicate well and to be able to go abroad when they have mastered English. In Indonesia, English is considered as foreign language and is taught formally from elementary until university level.

In order to mastering English there are four skills that should be mastered, they are: listening, speaking, reading, and writing. Reading is a skill that is important to be taught because according to (Finocchiaro and Bonomo, 1973:199)

Reading is bringing and getting meaning from the printed or written material. Reading comprehension is the ability to understand what has been read (Zimmerman, 2010).

However, base on the researcher observation in MTs. Tarbiyatul Mustafid, most of the students still have difficulties in comprehending an English text, getting information from the text, finding the main ideas, answer to the questions based on the text and making conclusion of the text. The facts indicate that they had low ability in comprehending English text so their reading score is average low. It is because reading in the classroom only focus on asking students to read the text and answering the question based on the text without facilitating them to comprehend texts properly. That is why the students feel bored and not motivated in the subject which demands the students to read.

Relate to the problem above, it is possible to the teacher to find the appropriate strategy to teach reading strategy that can make students easy to understand in learning and encourage students to be easily understand the reading material. The researcher tries to offer the strategy is called schema 
activation strategy. Schema Activation Strategy is a strategy which focuses on activating students background knowledge. Such steps as building interest and attention, assessing prior knowledge and exploring keywords, building connection between students' prior knowledge and the new material, and comprehending the new material were implemented in the teaching and learning process of reading. They influence much on the success of reading a text. According to Mardianti et,al (2014:2) schema activation strategy is a way of reading where the readers are expected to use a strategy to activate his/her own prior knowledge when they read English text or passage.

Relate with the study, there are some previous conducted the using of schema activation strategy, they are: First, Kurnia (2014) entitled "Improving the reading comprehension of grade VIII students at SMPN I Mlati using Schema Activation Strategy". The result of the research revealed that the use of schema activation strategy successfully to improve the student's reading comprehension.

Second, Fazri, Muhamad Alif (2013) entitled "Using Schema Activation Strategy to improve reading comprehension of grade $8 \mathrm{~B}$ ". The result of two cycles showed that that the use of schema activation strategy is effective to improve the student's reading comprehension. It's support by qualitative data which show that the students were able to use their prior knowledge to understand the text. The last Veti Mardianti (2014) entitled "Improving Student's Reading Comprehension through Schema Activation Strategy" the result by using schema activation strategy can significantly improve the student's reading comprehension.

From the explanation above, the researcher wants to conduct the research entitle "The use of schema activation strategy in teaching reading comprehension at the second grade students of MTs Tarbiyatul Mustafid in academic year 2017/2018".

\section{Method}

The research design of this study was Quasi Experimental Design. Acoording to Sugiyono (2014: 114) stated "it is developing from the experimental design. This design has a control group, but that group does not have full functions to control the variables outside of the research implementation". The researcher had investigated that the use of schema activation strategy in teaching descriptive text at the second grade student of MTs Tarbiyatul Mustafid in academic year 2016/2017, in that research the students was divided into two groups namely experimental and control group, only experimental group was taught by using schema activation strategy while the control group was not used.

The population is the group of people we wanted to generalise to (Muijs, 2004: 15). The population of this study was all the students at the second grade students of MTs. Tarbiyatul Mustafid in academic year 2016/2017 who have two classes were A class (30 students) and B class (30 students) so the total of number whole population was 60 students.

According to Arikunto, (2013) if the population more than 100 person, we taken only $10 \%$ $15 \%, 20 \%-25 \%$ (or more) of it can be taken but If the population less than 100 person, we take all of them as a sample.

The sample of this study was all the students at the second grade students of MTs. Tarbiyatul Mustafid in academic year 2016/2017 who have two classes those are A class (30 students) and B class (30 students) so the total of the sample is 60 students.

Based on the statement above the sample of this study took by using purposive sample. This technique is usually done becuase of some considerations, such as the limit of time, energy that is why can not take samples which is large and far (Arikunto, 2014: 183).

Sugiyono (2016: 148) says that instrument is a means to know the nature and social phenomenon that wants to observe. In this research, the researcher used the reading test in form of 25 numbers multiple choice. It was supposed to know the ability of the students before and after the researcher used schema activation strategy. The text about descriptive text in different story in question. The pre test and post test are descriptive text about person, place, animal and things. Both the test has same types of question. Each number of the test would be score 4, if the students answer correctly they will get score and if they answer is wrong they will get score 0 .

In this research used test as an instrument of collect the data, and the data was collect by gave pre-test and a post-test to the experimental group and control group.

a. Pre-test 
At the first meeting the researcher gave the students set of reading test which aim to know the students initial proficiency in adding before the treatment gave. The result of the test counted from the data compared with the result of the post-test. The students were given reading comprehension test in multiple choices item which consist of 25 questions descriptive text about people, place, animal, and thing. This test was aim in the testing the students reading comprehension.

\section{b. Treatment}

The second procedure the researcher taught the student in experimental group by using schema activation Strategy while the control group was taught by used other strategy. In other words, the treatment was only gave to the experimental group while the control was not. The material was conveyed by the researcher descriptive text about person, place, animal and thing.

c. Post-test

After conduct the treatments, the researcher administered post test to the students. The researcher gave multiple choice item test that consist of 25 numbers about descriptive text. The scoring system and degree of difficulty of the pre-test are similar to the post-test because both of items was used to measure the students ${ }^{\text {ee }}$ ability in reading comprehension through schema activation strategy.

Table 3.1: Table of Reading Score-1

\begin{tabular}{cccc}
\hline No & Qualification & Degree & Qualitative \\
\hline 1 & Excellent & $80-100$ & A \\
\hline 2 & Good & $70-79$ & B \\
\hline 3 & Fail & $60-69$ & C \\
\hline 4 & Poor & $50-59$ & D \\
\hline 5 & Complete poor & $0-49$ & E \\
\hline
\end{tabular}

Then the researcher analyzed the students result to find out their ability through their reading test result.

The researcher was used experimental research. The data are collects from the result of pre-test and post-test. In calculating the students' mean score of experimental group and control group, the researcher was used the following formula:

a. To find the students' mean score of experimental and control group, used the following formula:

$\mathrm{Mx}=\sum \frac{x}{N}$

$\mathrm{My}=\sum \frac{y}{N}$

Where: $\mathrm{Mx}=$ the mean score of experiment group

$\mathrm{My}=$ the mean score of control group

$\mathrm{x}=$ the total score for experimental group

$y=$ the total score for Control group

$\mathrm{N}=$ the number of sample

b. To find out the standard deviation of experimental group and control group. The formula of standard deviation as follow:

1) Find out the standard deviation of experimental group, the formula as follows:

$\sum \mathrm{x}=\sum \mathrm{x}^{2}-\frac{(\mathrm{x}) 2}{\mathrm{Nx}}$

Where:

$\mathrm{X}=$ the students standard deviation for experimental group

$\mathrm{N}=$ the number of sample 
2) Find out the standard deviation of control group, the formula as follows:

$\sum \mathrm{Y}=\sum \mathrm{y}^{2} \frac{(y) 2}{N y}$

Where:

$\mathrm{Y}=$ the students standard deviation for control group

$\mathrm{N}=$ the number of sample

c. The last, in the testing the significance of two variables standard deviation by using the following formula :

$$
T=\frac{\mathrm{Mx}-\mathrm{My}}{\sqrt{\frac{\sum x^{2}+\sum y^{2}}{(\mathrm{Nx}+\mathrm{Ny})-2}\left[\frac{1}{\mathrm{Nx}}+\frac{1}{\mathrm{Ny}}\right]}}
$$

Where:

Mx: Mean score of experimental group

My: Mean score of control group

$\mathrm{N}$ : Total numbers of the subject

$\mathrm{x}$ : The deviation of experimental group

$y$ : The deviation of control group

- If t-test $<$-table in the significance of $0,05(p=0,01)$, Ho is rejected. It means that the experimental groups have higher skill in reading than control groups.

- If $t$-test $>t$-table in the significance level of $0,05(p=0,01)$, Ho is accepted. It means that the control groups have lower skill in reading than experimental groups.

\section{Results and Discussion}

After gaining the data from pre-test and post-test score through schema activation strategy, the researcher analysis the data of this reseach. Firstly, the researcher processed those scores through some stages : the calculation and analysis of the mean score, the calculation and analysis of deviation score for two groups.

Table 4.1: The Deviation Scores of Pre-test and Post-test for Experiment Group-1

\begin{tabular}{cccccc}
\hline \multirow{2}{*}{ NO } & & \multicolumn{4}{c}{ Final Score } \\
\cline { 3 - 5 } & Students Name & $\mathbf{X 1}$ & $\mathbf{X 2}$ & $\mathbf{X}$ \\
$\mathbf{X 2 - X 1}$ & $\mathbf{X}^{\mathbf{2}}$ \\
\hline 1 & AGUS F & 56 & 80 & 24 & 576 \\
\hline 2 & AHMAD Z & 56 & 72 & 16 & 256 \\
\hline 3 & AMRUL B & 72 & 84 & 12 & 144 \\
\hline 4 & DEDE & 76 & 88 & 12 & 144 \\
\hline 5 & DIMAS & 80 & 84 & 4 & 16 \\
\hline 6 & FATUR & 80 & 80 & 0 & 0 \\
\hline 7 & FERI & 88 & 92 & 4 & 16 \\
\hline 8 & GILANG & 80 & 92 & 12 & 144 \\
\hline 9 & HIKMAL & 44 & 84 & 40 & 1600 \\
\hline 10 & HILAL & 56 & 80 & 24 & 576 \\
\hline 11 & KURNA & 64 & 76 & 12 & 144 \\
\hline 12 & ALFARI & 56 & 76 & 20 & 400 \\
\hline 13 & MUHAI & 88 & 60 & -28 & 784 \\
\hline
\end{tabular}




\begin{tabular}{|c|c|c|c|c|c|}
\hline \multirow[b]{2}{*}{ NO } & \multirow[b]{2}{*}{ Students Name } & \multicolumn{4}{|c|}{ Final Score } \\
\hline & & $\mathbf{X 1}$ & $\mathbf{X} 2$ & $\begin{array}{c}X \\
X 2-X 1\end{array}$ & $\mathbf{X}^{2}$ \\
\hline 14 & ABDUL & 64 & 96 & 32 & 1024 \\
\hline 15 & DARMA & 28 & 76 & 48 & 2304 \\
\hline 16 & KHAER & 56 & 76 & 20 & 400 \\
\hline 17 & MARZUKI & 68 & 80 & 12 & 144 \\
\hline 18 & MUZAEN & 44 & 84 & 40 & 1600 \\
\hline 19 & NABAHAN & 64 & 84 & 20 & 400 \\
\hline 20 & NAJI & 72 & 84 & 12 & 144 \\
\hline 21 & RIDO & 80 & 84 & 4 & 16 \\
\hline 22 & YUDA & 76 & 84 & 8 & 64 \\
\hline 23 & RISWANDI & 68 & 76 & 8 & 64 \\
\hline 24 & ROBI & 80 & 76 & -4 & 16 \\
\hline 25 & SALMAN & 44 & 84 & 40 & 1600 \\
\hline 26 & SOHIBUL & 52 & 80 & 28 & 784 \\
\hline 27 & FARIL & 88 & 84 & -4 & 16 \\
\hline 28 & SULTON & 96 & 84 & -12 & 144 \\
\hline 29 & AHMAD & 48 & 72 & 24 & 576 \\
\hline 30 & DIKA & 48 & 80 & 32 & 1024 \\
\hline & $\sum$ & 1972 & 2432 & 460 & 15120 \\
\hline
\end{tabular}

Where :
X1 : Pre-test
X2 : Post-test
$\mathrm{X} \quad$ : Deviation of pre-test and post-test in experimental group
$\mathrm{X}^{2} \quad$ : the square of the deviation scores in experimental group

Table 4.2: The Deviation Scores of Pre-test and Post-Test of Control Group-1

\begin{tabular}{|c|c|c|c|c|c|}
\hline \multirow[t]{2}{*}{ No } & \multirow[t]{2}{*}{ Students Name } & \multicolumn{4}{|c|}{ Final Score } \\
\hline & & Y1 & Y2 & Y2-Y1 & $\mathrm{Y}^{2}$ \\
\hline 1 & AMIRA RQ & 88 & 92 & 4 & 16 \\
\hline 2 & ANIS US & 48 & 60 & 12 & 144 \\
\hline 3 & ANISA FIT & 52 & 60 & 8 & 64 \\
\hline 4 & ARIFA & 72 & 88 & 16 & 256 \\
\hline 5 & AYUNI & 76 & 72 & -4 & 16 \\
\hline 6 & DESITA D & 72 & 80 & 8 & 64 \\
\hline 7 & HALIMA S & 28 & 72 & 44 & 1936 \\
\hline 8 & HARDIAN A & 64 & 72 & 8 & 64 \\
\hline 9 & ISMAWATI & 80 & 80 & 0 & 0 \\
\hline 10 & LAILATUL I & 84 & 84 & 0 & 0 \\
\hline 11 & LAILI H & 48 & 72 & 24 & 576 \\
\hline 12 & MASKAN A & 68 & 64 & -4 & 16 \\
\hline 13 & MAULIDINA & 20 & 48 & 28 & 784 \\
\hline 14 & MAYANI & 84 & 96 & 12 & 144 \\
\hline 15 & MELDINA ES & 84 & 84 & 0 & 0 \\
\hline 16 & MELIANA & 44 & 44 & 0 & 0 \\
\hline 17 & MIRATUN & 60 & 56 & -4 & 16 \\
\hline 19 & MUAIMIN & 76 & 68 & -8 & 64 \\
\hline 18 & NUHYATUN & 72 & 80 & 8 & 64 \\
\hline 20 & PRAMUDITA & 36 & 48 & 12 & 144 \\
\hline 21 & RINA S & 64 & 76 & 12 & 144 \\
\hline 22 & ROHANA & 80 & 72 & -8 & 64 \\
\hline 23 & SALFIRA & 72 & 76 & 4 & 16 \\
\hline 24 & SITI F & 76 & 76 & 0 & 0 \\
\hline 25 & TANALIN K & 80 & 68 & -12 & 144 \\
\hline 26 & UNIATI & 68 & 64 & -4 & 16 \\
\hline 27 & VINA NH & 84 & 76 & -8 & 64 \\
\hline 28 & WAHYU & 72 & 76 & 4 & 16 \\
\hline 29 & WINDA I & 64 & 68 & 4 & 16 \\
\hline 30 & WULAN S & 52 & 56 & 4 & 16 \\
\hline
\end{tabular}




\begin{tabular}{cccccc}
\hline \multirow{2}{*}{ No } & Students Name & \multicolumn{4}{c}{ Final Score } \\
\cline { 2 - 5 } & & Y1 & Y2 & Y2-Y1 & $\mathrm{Y}^{2}$ \\
\hline & $\sum$ & 1968 & 2128 & 160 & 4864 \\
\hline
\end{tabular}

Where:

$\begin{array}{ll}\text { Y1 } & : \text { Pre-test } \\ \text { Y2 } & : \text { Post-test } \\ \text { Y } & : \text { Deviation score from pre-test and post-test in control group } \\ \mathrm{Y}^{2} & : \text { The square of the deviation score in control group }\end{array}$

Based on the table of deviation score above, the researcher showed that the students deviation score of experimental group was 460 and control group was160. Later, the researcher explained the student's classifications reading score of experimental group were the students got excellent, good, fail, poor and complete poor in the table below.

Table 4.3: The Percentage of the Students' Score in the Pre-test of Experimental Group-1

\begin{tabular}{ccccc}
\hline No & Classfication & Degree & Frequency & Percentage \\
\hline 1 & Excellent & $80-100$ & 9 & $30 \%$ \\
\hline 2 & Good & $70-79$ & 4 & $13 \%$ \\
\hline 3 & Fail & $60-69$ & 5 & $17 \%$ \\
\hline 4 & Poor & $50-59$ & 6 & $20 \%$ \\
\hline 5 & Complete poor & $0-49$ & 6 & $20 \%$ \\
\hline Total & & 30 & $100 \%$ \\
\hline
\end{tabular}

Table 4.3 showed the percentage of the students score in pre-test of experimental group which was consists of 30 students. The result showed that the students who got category excellent was 30 $\%$, good $13 \%$, fail $17 \%$, poor $20 \%$, and complete poor $20 \%$.

Table 4.4: The Percentage of the Students Score in Post-test of Experimental Group-1

\begin{tabular}{|c|c|c|c|c|}
\hline No & Classification & Degree & Frequency & Percentage \\
\hline 1 & Excellent & $80-100$ & 21 & $70 \%$ \\
\hline 2 & Good & $70-79$ & 8 & $27 \%$ \\
\hline 3 & Fail & $60-69$ & 1 & $3 \%$ \\
\hline 4 & Poor & $50-59$ & 0 & $0 \%$ \\
\hline 5 & Complete poor & $0-49$ & 0 & $0 \%$ \\
\hline \multicolumn{2}{|c|}{ Total } & 30 & $100 \%$ \\
\hline
\end{tabular}

Table 4.4 showed the percentage of the students score in post-test of experimental group which was consists of 30 students. The result showed that the students who got category excellent was 70 $\%$, good $27 \%$, fail $3 \%$, poor $0 \%$, and complete poor $0 \%$.

In this section, the researcher presented the statistical calculation of obtained data, namely experimental group and control group. Then, the discussion covers the calculation of mean score of both control and experimental group. the statistical calculation covers the calculation of mean score both of experimental and control group. After getting the score deviation of pre-test and post-test above, then the next step was the calculation of mean and deviation score of the two groups. It can be formulated as follows:

1. Calculation of mean experimental group

a. Calculation of mean experimental group (Mx)

$$
\begin{aligned}
& M x=\frac{\sum x}{N} \\
& M x=\frac{460}{30} \\
& M x=15.33
\end{aligned}
$$

b. Calculation of mean control group (My) 
$\mathrm{My}=\frac{\sum y}{N}$

$\mathrm{My}=\frac{160}{30}$

$\mathrm{My}=5.33$

2. The Computation of deviation

a. Square deviation of experimental group 15.120

So, $\sum \mathrm{X}=\sum \mathrm{x} 2-(\mathrm{x}) 2$

$$
\mathrm{Nx}
$$

$\mathrm{X} 2=15.120-{\frac{(460)^{2}}{30}}^{2}$

$\mathrm{X} 2=15.120-\frac{211.600}{30}$

$\mathrm{X} 2=15.120-7.05333$

$\mathrm{X} 2=8.066,67$

b. Square deviation of control group 4.864

$\sum \mathrm{Y}=\sum \mathrm{y} 2-(\mathrm{y}) 2$

$\mathrm{Ny}$

$\mathrm{Y} 2=4.864-\frac{(160)^{2}}{30}$

$\mathrm{Y} 2=4.864-\frac{25.600}{30}$

$\mathrm{Y} 2=4.864-853,33$

$\mathrm{Y} 2=4.010,67$

After finding square deviation, the result of data analysis score is calculated to the score of t-test formula.

$$
t-\text { test }=\frac{\mathrm{Mx}-\mathrm{My}}{\sqrt{\frac{\sum x^{2}+\sum y^{2}}{(\mathrm{Nx}+\mathrm{Ny})-2}\left[\frac{1}{\mathrm{Nx}}+\frac{1}{\mathrm{Ny}}\right]}}
$$

Where: $\quad$ M: The mean score of each group

$\mathrm{N}$ : The number of sample

$\mathrm{X}$ : The standard deviation score of control group

Y: the standard deviation score of control group

$\sum$ : the sum of......

$\sqrt{ }:$ the root of....

(Arikunto, 2014: 354)

$$
t-\text { test }=\frac{\mathrm{MX}-\mathrm{MY}}{\sqrt{\frac{\sum x^{2}+\sum y^{2}}{(\mathrm{NX}+\mathrm{NY})-2}\left[\frac{1}{\mathrm{NX}}+\frac{1}{\mathrm{NY}}\right]}}
$$




$$
\begin{aligned}
& \mathrm{t}=\frac{15,33-5,33}{\sqrt{\frac{8.066,67+4.010,67}{(30+30)-2}[}} \\
& t=\frac{10}{\sqrt{\left[\frac{12.077,34}{58}\right]\left[\frac{2}{30}\right]}} \\
& \mathrm{t}=\frac{10}{\sqrt{208,23[0,06]}} \\
& \mathrm{t}=\frac{10}{12,4} \mathrm{t}=\frac{10}{3,5} \\
& \mathrm{t}=2.85
\end{aligned}
$$

The analysis of the data in this research is aimed to find out mean scores analysis, is it referred to the score of t- test 2.85 . Before the researcher check the table distribution. Firstly, the researcher determine the degree of freedom (df) that is $x+y-2=30+30-2=58$. Based on the table of level significance have been poin ted out, the coefficient t-test is directly checked on the table of $t$ distribution. Based on the table, the critical value of t-table on the level of significance t $0.05 \%$ is 2.021 and $t 0.01 \%$ is 2.704 . So, it is found that $2.85>2.021$ and 2.704 .

Based on the data analysis above, it was found that the result of t-test is higher than t-table. It means that alternative hypothesis which stated that the use of schema activation strategy was effective in teaching reading is accepted. Meanwhile the null hypothesis which stated that schema activation strategy has not effect in teaching reading is rejected

The researcher has investigated the use of schema activation strategy in teaching reading comprehension. Based on the research question formulated in chapter I, this research is aimed to investigate whether the use of schema activation strategy effective or not in teaching reading comprehension.

Referring to data interpretation that has been presented above, it was found the deviation score of pre-test and post-test for experimental group is 460 and control group is 160 . Continued the calculation computation of mean scores for the experimental group is 15.33 and for the control group is 5.33.from that explanation it showed that the score of experimental group higher than control group.

To check the significant effect of the treatment, the researcher analyzed by using t-test formula. The result of t-test was 2.85 . Then, the researcher checked the critical value on the t-table of significant level $0,05 \%$ was 2.021 and $0,01 \%$ was 2.704 . From the result, it was found that t-test was higher than t-table $(2.85>2.021>2.704)$. It could be concluded that the null hypothesis was rejected and it can be inferred that the use of schema activation strategy was effective in teaching reading comprehension.

The researcher treatment the students were formulated into four steps. They were building interest and attention, accessing prior knowledge and exploring key words, building connection between students prior knowledge and the new material, and comprehending the new material. Those steps were so called steps in schema activation strategy. First, Building interest and attention, in teaching and learning reading, this activity became an important activity. Once the students were interested in the lesson, they felt at ease in understanding the lesson and learning reading ran well. The researcher selecting the topic also considered how far the topic could attract the students 'interest and how far the students were familiar with the topic. When the students were attracted and familiar with the topic, activating the students 'prior knowledge and exploring their vocabulary became easier.

The second steps was accessing prior knowledge and exploring key words. In this step, the researcher asked the students some questions related to the topic introduced. Those questions were about what the meaning of the topic was, what the students have already known about the text, and about things in the text. According to Willis (2008: 131), these activities belong to exploring key words. The purposes of this activity were improving the students' vocabulary and preparing them before reading new materials. 
The third, building connection between students 'prior knowledge and the new material. The purpose of this step make students knew the importance of relating their prior knowledge to the new material. The researcher asked the students predict the text by looking at the title of the text. The activity was effective in making students used their prior knowledge in order to predict the content of the text.

The last step comprehending the new material, reading the text in depth became the activity in comprehending the new material. During the process of reading, the students read the text and connected it with their background knowledge. They were asked to find the new information they got from their reading like difficult words. In this step also the students were stimulated to relate what they had in their background knowledge to the new information in the text. It meant that there was interactive process during reading as it said by Brown (2001:298-299). Furthermore, the students were also presented a set of reading comprehension questions. It used to evaluate the students understanding toward the content of the text.

Comprehending the new material was the final step in Schema Activation Strategy. It was regarded to be successful as the students could accomplish the task well.

\section{Conclusion}

Based on the result of the study, it could be concluded that the use of schema activation strategy was effective in teaching reading comprehension at the second grade students of MTs Tarbiyatul Mustafid in academic year 2017/2018. This skill has been proved by analyzing data from the result between the deviations of mean scores of experimental group was 15.33 and control group was 5.33. Then the result of the statistical analysis of t-test in this research was 2.85 . It was higher that critical values for t-table in degree of freedom (df) 58 is $2.021(0.05 \%)$ and $2.704(0.01 \%)$. From this fact, it was clear that mean score of both groups has a difference. It means the alternative hypothesis (Ha) was definitely accepted.

From the result, the researcher concluded that the schema activation strategy was effective in teaching reading comprehension at the second grade students of MTs Tarbiyatul Mustafid in academic year 2017/2018

\section{References}

1. Aebersold, J. A., \& Field, M. L. 1997. From Reader to Reading Teacher. Cambridge: Cambridge University Press.

2. Ajideh, Parviz. 2003. Schema Theory - Based Pre - Reading Tasks: A Neglected Essential in the ESL Reading Class. The Reading Matrix. Vol III No I, Pages: 2-8.

3. Alderson, J.C. 2000. Assessing Reading. Melbourne: Cambridge University Press.

4. Anderson, Mark. 1997. Text Type in English 2. Australia: Mackmillan.

5. Arikunto, S. 2014. Dasar-dasar Evaluasi Pendidikan. Jakarta: Bina Aksara.

6. Bransford, J. D. 2004. Schema activation and schema acquisition: Comments on Richard C. Anderson"s remarks. In R. B. Ruddell, \& N. J. Unrau (Eds.), Theoretical models and processes of reading (5th ed.) (pp. 607-619). Newark, DE: International Reading Association, Inc.

7. Brown, H. D. 2001. Teaching by Principles: An Interactive Approach to Language Pedagogy. White Plains, NY: Addison Wesley Longman, Inc.

8. Carrel, P. L. 1988. Interactive Text Processing; Implications for ESL/Second Language Reading. Cambridge: Cambridge University Press.

9. Citra, K. 2014, A thesis: Improving students reading comprehension using schema activation strategy: unpublished.

10. Clark, M and Silberstein, S. 1987. Toward a Realization of Psycholinguistic Principle in the ESL Reading Class, in Methodology TESOL. New York: New Bury House Publisher.

11. Cook, G. 1989. Discourse in 'Language Teaching: A Scheme for Teacher Education'. Oxford: Oxford University Press.

12. Grabe, W. 1991. Current Developments in Second Language Reading Research. TESOL Quarterly.

13. Harmer, J. 2001. The Practice of Language Teaching (3rd Ed). London: Longman Group Ltd.

14. Hatch, E and Farhady. 1982. Research Design and Statistic for Applied Linguistics. London: New Bury House Production, Inc. 
15. Hughes, A. 1991. Testing for Language Teachers. Great Britain, Glasgow: Cambridge University Press.

16. Mackay, R. 1979. "Teaching the information- Gathering Skill”. Reading in a Second Language. Mass: Newbury House Publishers.

17. Meyers, A. 2005. Gateways to Academic Writing: Effective Sentences Paragraph and Essay. New York: Longman.

18. Mikulecky, B. S. 1989. A Short Course in Teaching Reading Skills. New York: Addison - Wesley Publishing Company.

19. Moreillon, Judy. 2007. Collaborative Strategies for Teaching Reading Comprehension. Chicago: American Library Association.

20. Nunan, David (Ed). 2003. Practical English Language Teaching. New York: McGraw-Hill

21. Richards, J. C. and R. Schmidt. 2002. Longman Dictionary of Language Teaching and Applied Linguistics. London: Pearson Education Limited.

22. Shahan, T., and Lomax, R. G. 1986. An Analysis and Comparison of Theoretical Models of the ReadingWriting Relationship. Journal of Educational Psychology, 78, 116-123.

23. Snow, C. 2002. Reading for Understanding: Toward an R\&D Program in Reading Comprehension. Santa Monica, CA: RAND Corporation. 